\title{
SEMI-DOMESTICATION OF BUMBLEBEES IN SASKATCHEWAN
}

PHILIP CURRY, Agriculture Canada Research Station, Box 1240, Melfort, Saskatchewan SOE 1A0, and JOHN DALGLEISH, Melfort, Saskatchewan.

Bumblebees are widely distributed in the northern hemisphere, some living as far north as Ellesmere Island in Canada's arctic. They are most abundant both in number of species and number of colonies in the north temperate zone. North America has about 50 species or subspecies, of which 19 have been found in Saskatchewan (Table 1). The greatest concentration of bees occurs in the aspen parkland areas. Fewer species exist on the prairie, and they are more scattered.

\section{Life Cycle}

Bumblebees are social insects like honeybees. Each colony has one queen who produces workers in summer and drones and new queens in early fall. The new queens mate, spend the winter in hibernation, and start new colonies the following spring. Some species build their nests underground. Others build in the shelter of a carragana hedge, or in rock piles, or beneath old piles of lumber.

The general biology of bumblebees has been well outlined by Free. ${ }^{1}$ The mated queen emerges from hibernation, between early spring and early summer, depending on the species. During the next few weeks she consumes nectar and pollen from early flowers (willow, dandelion, carragana). When she emerges from hibernation, her ovaries are small and threadlike, but after several weeks of feeding they become enlarged and the first eggs develop. Now the queen may be seen flying low over undisturbed ground along hedges, banks or untended areas in search of a suitable nesting site. Most often the site selected is an abandoned nest of a mouse or bird, and consists of an accumulation of grass, moss or leaves.

After selecting her site the queen forms a hollow in the center of the material which was accumulated there and during the next few days she makes a clump of pollen on the cavity floor and builds a wax cup on top of it in which she lays eggs; she then seals the top of the egg cell with more wax and constructs a wax honey pot, which she fills with honey as a reserve in case of inclement weather.

When the larvae hatch, they feed on their bed of pollen and on nectar and pollen which the queen regurgitates to them through temporary breaches that she makes in their wax covering. As a result they grow rapidly and the queen keeps adding more wax to their covering so they remain completely enclosed. After about ten days the larvae spin their cocoons and pupate. The queen removes the wax from the outside of the cocoon and uses it to make egg cells on top of them.

The development of egg to adult bee takes 3-4 weeks depending on the environmental temperature and food supply. The size of the workers depends on the amount of food they receive in the larval stage; since spring forage may be in short supply, and the queen must collect all the 
TABLE 1: Occurrence of bumblebees in Saskatchewan.

\section{Bombus}

B. appositus Cresson

B. bifarius bifarius Cresson

B. borealis Kirby

B. californicus Smith

B. centralis Cresson

B. frigidus Smith

B. fervidus fervidus Fabricus

B. huntii Greene

B. nevadensis nevadensis Cresson

B. perplexus Cresson

$B$. rufocinctus Cresson

B. ternarius Say

B. terricola occidentalis Greene

$B$. terricola terricola Kirby

$B$. vagans vagans Smith

\section{Psithyrus}

P. ashtoni (Cresson)

$P$. fernaldae Franklin

$P$. insularis (Smith)

P. suckleyi (Greene)

food herself, the first workers are smaller than those produced later.

At first, the new workers help the queen to forage for food and rear fresh broods, but soon they take over foraging entirely. The queen remains in the nest, laying successive batches of eggs and helping to rear the brood.

In northern areas the size of a bumblebee colony at the climax of its development is relatively small. Depending on the species and environmental factors during development, anywhere from 10 to 400 bees may be produced in a single season; a colony of 30 to 50 is more usual for northeastern Saskatchewan. At the climax of colony development, male bees are produced from unfertilized eggs and queens, like workers, are produced from fertilized ones. Externally, queens look like very large workers. Males leave their nests when they are
Distribution

- prairie areas, rare

- woodland, rare

- woodland-prairie, common

- woodland, rare

- woodland, rare

- woodland, rare

- prairie, common

- prairie, common

- woodland-prairie, common

- eastern woodland, common

- woodland-prairie, common

- woodland-prairie, common

- woodland-prairie, rare

- woodland-prairie, common

- woodland, common

- eastern woodland-prairie, rare

- woodland, rare

- woodland-prairie, common

- woodland-prairie, common

a few days old and seldom return, but young queens remain close to the nest for some time. Mating generally takes place on the wing, and a queen may mate several times. After mating they feed liberally on both nectar and pollen and store large reserves of fat in their body. At this time they often forage for their maternal colony. Early in fall they go into hibernation. Most species bury themselves a few centimeters beneath the soil or beneath leaves or other matted vegetation. Less commonly, other sites may be chosen.

Bumblebees are extremely efficient pollinators, but they are usually too few in number to pollinate large areas of agricultural crops. Their numbers fluctuate from place to place and from year to year so that even though they are abundant one year they may be scarce the next. Because of their value to crops, scientists have looked for ways to 
rear bumblebees in artificial nests to increase the population in an area or to obtain colonies which can be moved.

Modern agricultural production methods have been a mixed blessing for bumblebees. On the one hand natural nesting sites such as shelterbelts, banks, and aspen bluffs disappear as the size of field units are increased. Herbicide usage destroys many weeds which are important sources of food to bees, especially just after they have emerged from hibernation. Insecticides, if applied to crops in flower, may kill the visiting queens and prevent the establishment of colonies. On the other hand, seeding large fields to legumes or other flowering crops provides a large food supply in a small area and maintains the wild bee population. In northeastern Saskatchewan, bumblebees are important for pollinating red clover fields.

Interested persons can successfully increase nesting sites for bumblebees around farms or in town, or obtain colonies for biology classes in schools and colleges by using simple equipment and techniques developed by scientists. Two methods have been used: some researchers have captured queens in spring and have persuaded them to nest by confining them for a period in hives with food and nesting material. ${ }^{7}{ }^{10}$ Others have set out hives containing nesting materials in suitable habitats and permitted queens to colonise them. ${ }^{25}$ Our work in northeastern Saskatchewan has used the second method to obtain colonies for pollination and population studies.

\section{Nest box Construction}

The nest boxes we use are similar to those described by Hobbs et $\mathrm{al}^{5}$ (Fig. 1). They are constructed from
$1.3 \mathrm{~cm}(1 / 2$ inch) plywood with inside dimensions of $18 \times 15 \mathrm{~cm}(7 \times 6 \times 6$ inches). A $3.2 \times 4 \mathrm{~cm}\left(1 \frac{1}{4} \times 1 \frac{1}{2}\right.$ inch) block of wood $13 \mathrm{~cm}$ (5 inches) long is glued or nailed vertically to the inside of the short side of the box. An entrance hole $14 \mathrm{~mm}$ (9/16 inch) is drilled in the middle of the short side of the box and through the inside block of wood. The entrance shoula' be at an angle either upward or downward. Entrance holes of this type and dimension have proved extremely resistant to mice. A roof, $20 x$ 27 ( $8 \times 10 \frac{1}{2}$ inches) is fastened to the box with either eye-screws or hinges. A screened ventilation hole is provided somewhere near the top of the box. Finally the outside of the box is painted with a light and heat reflecting paint such as silver or white. Black strips, dots or circles should be painted around the entrance hole to aid in the orientation of the bees.

\section{Placement of nest boxes}

The hives should be lined with 1.37 $\mathrm{cm}(1 / 2$ inch) thick layers of upholsterer's cotton (Fig. 1) and set out in early spring before the leaves appear on the trees. Above-ground nests are nailed to stakes and positioned at least a few centimeters above the soil surface. They should be located in sites that bees frequent and preferably be near sources of abundant forage planits. They should be placed in groups beside aspengroves, along fences, rock piles, tree shelterbelts, hedges or creek banks. Abandoned farmsteads are often good locations. It is important to orient the entrances to face in different directions and to place each nest near some identifying landmark or the queens may enter each other's nest in error, and this may cause fighting. Once the boxes are sited, do not alter their position. North facing exposures or those exposed too much to wind and sun should be 


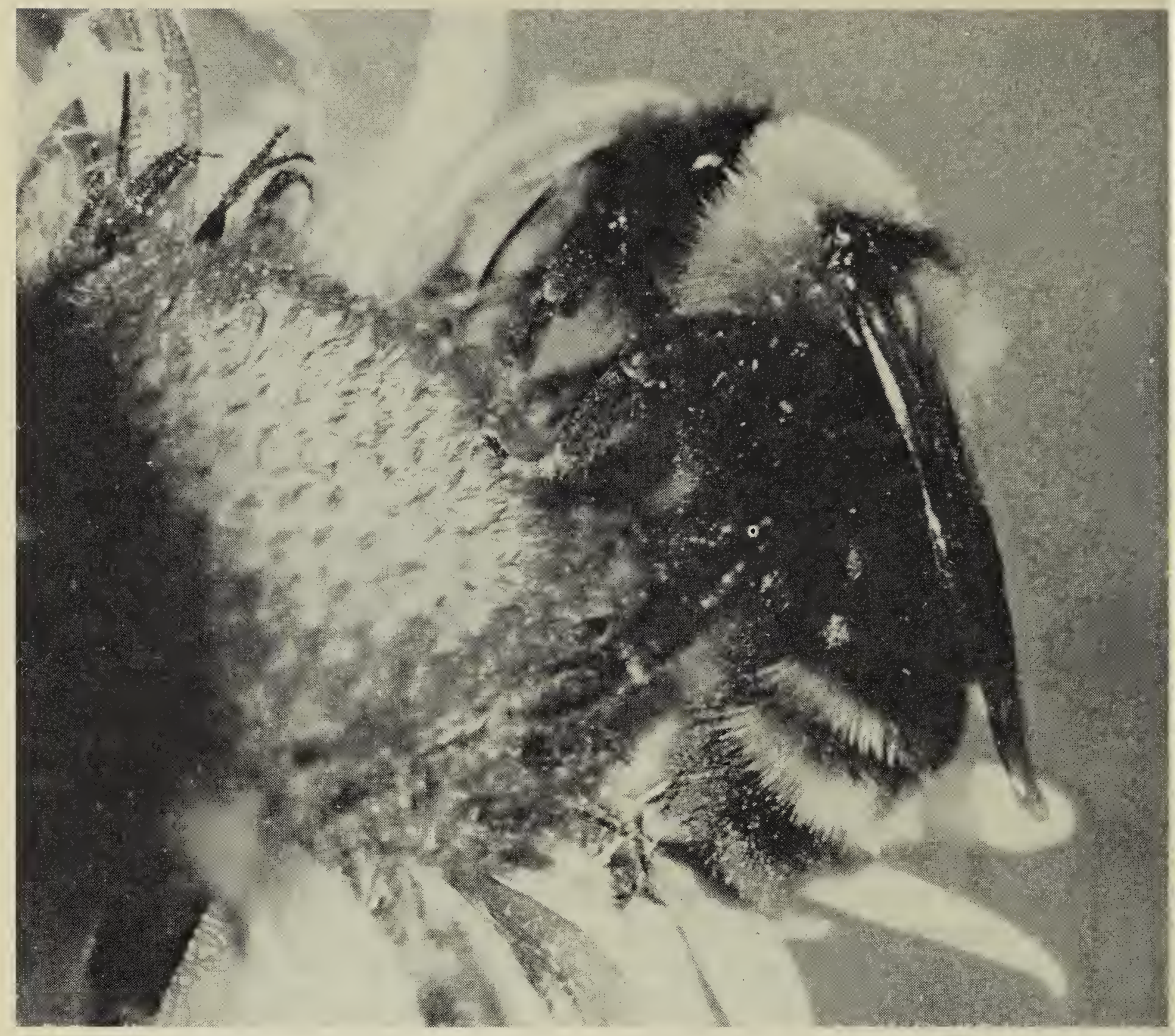

A bumblebee feeding at a Gaillardia

Fred W. Lahrman

species encountered in nest boxes. Fewer numbers of $B$. borealis and $B$. nevadensis will be found. In southern Alberta, Hobbs et $\mathrm{al}^{6}$ also recorded some success with $B$. fervidus and $B$. huntii. In northeastern Saskatchewan, two woodland species, $B$. perplexus and $B$. vagans readily accepted the artificial domiciles. Establishments in prairie areas are usually lower than in wooded areas because of lower population densities. Several common ground nesting species do not readily accept artificial nesting sites; including $B$. ternarius and $B$. terricola.

When a queen occupies a nest box, she completely rearranges the cotton to form a homogeneous mass with a hollow chamber in the center. Then, the brood and honey pot are constructed. We have generally considered a colony to be "established" if the wax cells containing the eggs have been built and the honey pot is present.

Colonies at this stage of nest building may be easily examined to identify the species present. Gently lift the lid from the nest box and separate a bit of the cotton to expose the brood chamber. If present, the queen will usually assume a defensive posture on her back, with her abdomen and stinger thrust forward. She may be manipulated gently using a pencil or slender stick in order to identify the species. If this 
TABLE 2: Common native and domesticated plants suitable for bumblebee forage.

Native species: willow spp. (pollen), dandelion, wild rose, sow thistle, gooseberry, wild currants, honeysuckle, blue bell, wild sweet pea, wild vetch, dogwood, bunch berry, wild strawberry, wild raspberry, fireweed, aster spp., goldenrod, Indian paint brush, bearberry, cranberry, blueberry. Forage crops: alfalfa, sweetclover, red clover, white dutch clover, alsike clover. Other crops: rapeseed, mustard, sunflower, buckwheat. Garden: rose, raspberry, strawberry, lilac, cotoneaster, crabapple, cherry, carragana, delphinium, nasturtium, iris, aster, cinquefoil (pollen), hollyhock.

examination is done too early or in a rough manner the queen may abandon the nest and not return.

\section{Foraging by bumblebees}

Bumblebees are dependent on flowers for all their food. The sugars in the nectar provide them with the carbohydrates necessary for both adults and brood. Pollen supplies the proteins vital for brood rearing.

Experiments by Kugler $^{8}$ have shown that bumblebees perceive colours of the spectrum but at shorter wave lengths than people. They can distinguish between blue, green and yellow; and can also detect different shades of these colours. Bumblebees cannot see red, which has a longer wave length. Many blue and yellow flowers (e.g. aster, goldenrod) are visited by bumblebees. Flowers exhibiting a colour contrast such as the variegated purples, yellows and greens of some alfalfa varieties are also attractive to bumblebees.

Bumblebees forage in much more unfavourable weather and earlier and later in the day than honeybees do. Bombus ternarius, for example, forages quite readily at $10^{\circ} \mathrm{C}$. In the summer months they forage from dawn to dusk, and often spend the nights in the particular field where they are working. They are likely to remain constant to any crop which provides them with plenty of pollen and nectar. ${ }^{4}$

An adequate and nearby supply of flowering plants with blooming periods covering the entire growing season is essential when establishing bumblebee colonies. Bumblebees are strong fliers and will readily desert an area if good nectar and pollen sources are not near at hand.

Do not attempt to keep bumblebees in heavily urbanized areas unless there are flowering trees or shrubs, and a variety of annual or perennial flowers, or some grass with clover nearby. Gardens around the farmyard or suburban home can be excellent sources of forage, if good-sized patches of flowers are planted. A list of native or domesticated flowers especially popular with bumblebees is listed below (Table 2). This list refers particularly to northeastern Saskatchewan, but will prove valid for most other areas on the prairies. Meticulous observation of bees foraging in the field will usually determine the best plants to have available.

\section{Hibernation}

The length of the hibernation period (diapause) varies greatly between different species and also between queens of the same species. In order to ensure the well-being of the overwintering queens, areas of undisturbed ground are necessary. Most queens will probably make use of abandoned mouse nests in grassy and wooded places. Unfortunately, many can be lost by using stubble fields which are then cultivated in late fall or early spring. Many queens will 
hibernate close to their maternal colony and some will establish nests at the same site the next year. Results of experiments in Melfort showed that young queens, marked the previous fall, often established the next spring in their maternal nesting site.

The queens of $B$. ternarius and $B$. terricola are vigorous (on emergence) and will fly and feed immediately. Some queens such as $B$. nevadensis, appear later and seem weak and sluggish on emergence. They may take several days to recover sufficiently for flight and foraging activities.

Most people will be content with the establishment and observation of bumblebee colonies during summer. Artificial wintering procedures have been attempted by several authors. ${ }^{109}$ The work involved was quite time consuming and success was limited. Spring care of overwintered queens, in particular, entailed a great deal of work.

\section{Pests and parasites}

Bumblebees have many natural enemies, ranging from badgers or skunks to minute protozoans and nematodes. Mice and ants commonly destroy nests and tiny parasitic mites are often in the nests. In Saskatchewan, however, the parasitic bumblebee (Psithyrus) is the worse menace.

The four species of Psithyrus found here resemble other bumblebees in color but have no pollen baskets on their hind tibiae. They produce no worker bees, only males and queens; the mated queens emerge from hibernation a few weeks later than other bee species. The Psithyrus queen finds a bumblebee colony by its scent, and enters the nest quietly so that the workers are not alarmed. She may drive out or kill the resident queen immediately or after several weeks of cohabitation. ${ }^{6}$ The workers accept the Psithyrus as their new queen; she lays her eggs, and the workers feed and tend the larvae as if they were their own. Psithyrus females make no contribution to the maintenance of the nest; colonies thus infested tend to be small, weak, and of little practical value for pollination.

'FREE, J. B. 1970. Insect Pollination of crops. Academic Press. New York.

${ }^{2} \mathrm{FYE}, \mathrm{R}$. E. and J. T. MEDLER. 1954. Field domiciles for bumblebees. J. Econ. Ent. 47:672-676.

${ }^{3}$ HASSELROT, T. B. 1960. Studies on Swedish bumblebees (genus Bombus Latr.): their domestication and biology. Opusc. Ent. Supple. 17:1192.

${ }^{4} \mathrm{HEINRICH}$, B. 1979. Bumblebee economics. Harvard University Press. Cambridge.

${ }^{5}$ HOBBS, G. A., J. F. VIROSTEK, and W. O. NUMMI. 1960. Establishment of Bombus spp. (Hymenoptera: Apidae) in artificial domiciles in Southern Alberta. Can. Ent. 92:868872.

${ }^{6} \mathrm{HOBBS}$, G. A., W. O. NUMMI, and J. F. VIROSTEK. 1962. Managing colonies of bumblebees (Hymenoptera: Apidae) for pollination purposes. Can. Ent. 94:1121-1132.

${ }^{7} \mathrm{HOLM}, \mathrm{S}$. N. 1960. Experiments on the domestication of bumblebees (Bombus Latr.) in particular B. lapidarius $L$. and $B$. terrestris $L$. Royal Vet. and Agric. College Year Book. Denmark. 1-19.

${ }^{8}$ KUGLER, H. 1943. Hummeln als Blütenbesucher. (Bumblebees as flower visitors.) Ergebn. Biol. 19:143323.

${ }^{9}$ MORGAN, P. and M. PERCIVAL. 1967. The rearing and management of bumblebees for students of biology. Bee World. 48:100-109.

10PLOWRIGHT, R. C. and S. C. JAY. 1966. Rearing bumblebee colonies in captivity. J. apic. Res. 5(3):155-165. 